\title{
CLUSTER DEVELOPMENT IN RURAL AREAS
}

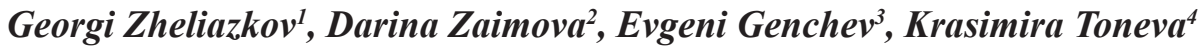

\begin{abstract}
Summary
The interest in creating a base-line for development patterns of clusters and clusters'specific characteristics in rural areas is particularly imposed by certain problems, which manifest themselves in similar degrees and provide a generic pattern in different regions and countries, e.g. depopulation and land abandonment, unemployment level and insufficient access to basic services and infrastructure. Certain development patterns and priorities are identified in the regional development in the old EU-members, while the member states from the Eastern parts are still partially restricted by their economic situation and political instability. This puts forth the concept of the "integration maturity", which refers to the preparedness of each country and its capability to fully exploit the benefits and the advantages of the integration form (Palánkai, 2003), and is still applicable in terms of the economic convergence level of the new-member states in comparison to the EU-15. This statement is especially relevant to the rural business and development that often remains distant and isolated from capital and sources of information and support. With the consequences of the economic crisis and the ongoing economic instability economists, business experts and social scientists have refined a broad range of techniques for making sense of regional economies and analyzing the public policy implications of their workings. Clusters are therefore often perceived not only as patterns for economic transactions and economic outcomes, but also as social systems and multidisciplinary environmental drivers for change.
\end{abstract}

Key words: clusters, shared value, rural areas, rural development.

JEL: $018, P 25, Q 18$

1 Georgi Zheliazkov, Ph.D., Full Professor, Trakia University, Student Campus, 6000 Stara Zagora, Bulgaria, Phone: +359 426994 17, E-mail: george-zh@mbox.digsys.bg

2 Darina Zaimova, Ph.D., Associate Professor, Trakia University, Student Campus, 6000 Stara Zagora, Bulgaria, Phone: +359 426992 71, E-mail dzaimova@gmail.com

3 Evgeni Genchev, Ph.D., Associate Professor, Trakia University, Student Campus, 6000 Stara Zagora, Bulgaria, Phone: +359 426994 35, E-mail: evg_gen2000@abv.bg

4 Krasimira Toneva, Ph.D., Chief Assistant, Trakia University, Student Campus, 6000 Stara Zagora, Bulgaria, Phone: +359 426994 12, E-mail: k toneva@abv.bg.

EP 2015 (62) 1 (73-93) 


\section{Introduction}

Rural clusters and networks are generally perceived as one of the drivers that lead to renewed economic growth and bring about competitiveness in the less developed areas. Cluster approach through its collaborative and cooperative activities target broad range of economic, social and ecological problems to ensure rural recovery and sustainability and "reinforce the progressive predilection for an economic system that balanced competition with cooperation, individualism with collectivism, and growth with equity" (Rosenfeld, 2009). Recently, clusters have become part of the mainstream of economic development and political agendas, targeting public attention not only to the economic results of the cluster approach, but also as solution to problems related to areas with lower level of education, labour mobility, resources and technology-based growth opportunities. In Europe rural areas are often associated with these problem categories. Policies and relevant development mechanisms have set as a straightforward priority reviving and sustainability of these areas, which are of utmost importance for the future. However, with the economic instability and crisis consequences it became apparent that the rurality suffers the most from the shortcomings in the social, economic and health system.

Rural regions represent up to $90 \%$ of the European territory and $54 \%$ of its population. Predominantly rural regions in the EU represent $52 \%$ of the territory and $23 \%$ of the population. In 2010 these regions generated $16 \%$ of the total GVA and $21 \%$ of the employment (European Commission, 2013). In 2012, 15.6\% of EU-27 population was younger than 15 years, the working-age population (between 15 and 64 years) represented $66.6 \%$ of the total and elderly people (65 years and above) accounted for $17.8 \%$. Still statistics also report that the share of elderly people has become bigger in all types of regions in relation to both the younger and the working-age population. Predominantly rural regions had the lowest level - 70\% of the EU-27 average GDP per capita, followed by intermediate regions (87\%). GDP per capita varies greatly at Member State level: the GDP per capita in predominantly rural regions of Bulgaria represented just $28 \%$ of the EU-27 average during the period 2008-2010, whereas in the Netherlands it was $148 \%$. Therefore the general promotion of rural development requires effective external inputs to gain sufficient results and capability of further improvements. In this relation endogenous development is put forth to emphasize comprehensive local development for human rights advocacy, human development and qualitative progress of living standards based on environmental conservation and sustainable social development. Within these framework inter-industrial relationships through comprehensive utilization of local resources, techniques, industries, human resources, cultures, and networks placing value on mixed economic working situations are needed to promote cooperation between cities and local economy.

All these processes have constantly caused local restructuring in a manner less favourable for the small-scale producers and enterprises, facing the difficulty to gain market spot or access to credit and other financial resources. Their position has even been worsened by acquiring of some specific niche products (in respect to their quality and regional characteristics) by the large companies. Hence, the quality that once was found only in small-scale firms' products could be guaranteed by the quality brands of competitive 
enterprises. Many traditional productions that failed to adjust to the new institutional circumstances and to apply new technological strategies ceased their existence. While developing their quality and improving their production technology certain types of productions have experienced a process of de-territorialisation and standardization. Strong regional identity was therefore preserved where local production systems have emerged, based on small-scale production. Specificity of different productions has influenced the institutional measures and initiatives that could be characterized in the light of both localization and broadening of industrial scope. Localization through intensified interaction and cooperation is perceived as a viable strategy of defence.

The creation, and sometimes reconstruction, of rural clusters is almost always built upon existing competencies and connections. Once established, two types of strategies are most often associated with their further development. The first one is "specialization" directly relevant to a particular kind of industry, while the second one is "association" based on the relationships and interactions among local firms. Drivers of cluster change could be summarized in four groups: political, economic, social and technical. The political factors are usually associated with the large consensus between public authorities and private sector representatives; high influence of unions and organizations; promotion of high quality and origin of production; and focus on the environmental policy. The economic factors are mainly related to the long-standing tradition resulting from a large number of local firms; concentration of retail system; and the competitive advantage of local production. Any progress in social or environmental results are the by-product of competiveness-driven initiatives, in most of the cases driven by resources directed toward those results by rural clusters, by recognition of the market value of socially responsible products, or by the explicit purpose of the cluster itself.

\section{Methodology and data sources}

The present paper is aimed to set the scene by providing the background information on the rationale, framework conditions and developed understanding on clusters and the shared value concept. Therefore a concise overview of relationships between the theory, cluster-specific framework conditions and rural development will be provided to shed light on what cluster is and where its boundaries lie in view of the emerging problems and social instability to deal with.

The structure of the paper will reflect the theoretical background of clusters, identifying them as certain dynamic social and organizational structures that hold different interlinked innovation stakeholders and tend to develop a set of institutions, networks, trust and shared value. Further the genesis of clusters and their development will be identified as a complex process, often dependent on various and even opposing players, e.g. government agencies, public organizations, different cooperative organizations, financial structures and educational institutions. The way their interaction mechanisms are operationalized, creates different level of competitiveness for the regions and varying capacity to enhance economic growth and social stability. It is therefore necessary to operationalize the cluster concept within the following three components: 
- Business and social value - anticipating how a degree of change in a social condition will drive profits, through either incremental sales or reduced costs, and linking those benefits to the resources needed to achieve them. It is an iterative process that considers how much social change is needed to unlock business value, strategies for achieving that change, and the possibility of getting others to invest in the initiative;

- Intermediate measures and track progress - a road map to monitor the initiative's progress in achieving the targeted social and business benefits. The goal is to validate (or invalidate) the anticipated link between social and business results, see which approaches do and don't work, and refine the initiative accordingly;

- Shared value produced - the ultimate social and business benefits helps firms expand to new areas and justify additional investment.

The data involved in the research overview encompasses rural development and its particular characteristics in order to implement the "value-chain" method of mapping clusters. This will allow to identify links between business cluster entrepreneurs, workers and organizations, and also to detect poorer groups within the cluster and to understand the poverty alleviation effects of different categories of firms on its workers. Within these limits certain characteristics appear in the development trends of rurality.

\section{The theory of clusters and social value added}

The concept of industrial clusters was first introduced by Alfred Marshall in 1920 (Marshall, 1920). For many years this term had a predominantly theoretical meaning up to the 1990's when the attention of academia was caught again. One of the new occurrences of the term cluster is in the work of Porter (Porter, 1990), as "a group of close-by, supporting industries creates competitive advantage". In his next publication on this topic he gives the following definition: "Clusters are geographic concentrations of interconnected companies and institutions in a particular field. Clusters encompass an array of linked industries and other entities important to competition" (Porter, 1998). The author periodically returns to "his old love" the concept of clusters, and in 2007, in a new publication, he finally defined the term clusters as "geographic concentrations of firms, suppliers, support services, specialized infrastructure, producers of related products, and specialized institutions (e.g., training programs and business associations) that arise in particular fields in particular locations" (Porter, 2007).

Other researchers have also given their contribution towards the definition of the concept of clusters:

- "Economic clusters are not just related and supporting industries and institutions, but rather related and supporting institutions that are more competitive by virtue of their relationships" (Feser, 1998);

- "Clusters can be characterised as networks of producers of strongly interdependent firms (including specialised suppliers) linked each other in a value-adding production chain" (Roelandt, den Hertog, 1999). 
After the year 2000, academic emphasis was focused not as much towards the essence, but rather towards the examination of the characteristics of clusters, the ways of identifying them, as well as their influence on the market environment. Every operating cluster has some common characteristics (Bergman, Feser, 1999):

1. Clusters are managed by entrepreneurs and public subjects;

2. The cooperation and competition are fundamental;

3. Fixed relations between companies and public administration institutions;

4. Cluster is a system where every member is of the same importance;

5. Cluster members have the common technologies, customers, distribution channels or labour markets and human capital.

Development of cluster typology is part of the overall clusters' conceptual development. The Scandinavian school of thought represented by Sölvell et al. (2003) makes an interesting differentiation between static and dynamic clusters. They underline that the evolution of a cluster is directly influenced by the microeconomic environment and the general business environment. A dynamic cluster benefits from strong business environment factors and tends to transform its members into internationally competitive companies, where a static cluster tends to "produce" only locally competitive companies. Enright (2000) identifies in his work four types of clusters:

1. Latent clusters - there is a critical mass of companies in related industries, who can benefit from a cluster, but the link between them is not strong enough to benefit from the co-location factors; usually there is a lack of information about other local companies, lack of trust, no common projects;

2. Potential clusters - we can find the necessary elements for a cluster, but the lack of interaction, or the gaps in the services and information flows impede the cluster development;

3. Policy driven clusters - are supported by the government usually based on other type of factors besides the economic factors; these types of clusters are failures or have a short life cycle;

4. Wishful thinking clusters - are ideal types of clusters, policy driven clusters without any critical mass of companies.

Nowadays, the precise identification of the clusters themselves is of special importance. Attempts in this direction have been made by Porter, as well as other authors (Sölvell et al., 2003). According to the level where the clusters are analyzed, some primary methods of differentiation: national (macro-level), industrial branch (mezzo-level) and firm level (micro-level), can be recognized (Stejskal, Hajek, 2012). The increased interest of society towards clusters is due to a number of reasons, the most important among which are:

- The participants in a given cluster can increase their productivity through their 
increased availability for access to production factors, such as human capital, information technologies, etc.;

- The cluster participants themselves have the economic benefit of attracting new participants, and they also facilitate the increase of their competitiveness;

- The presence of clusters formed by firms in a given region makes the planning of specific economic activities easier to accomplish, as well as more accurate predictions with regard to company behaviour.

The development of information technologies allows for the formation of new clusters, the so-called E-clusters (Davidovic, 2014). The factors facilitating their occurrence are numerous, yet macroeconomic policy has a crucial impact on development and growth of clusters, because it determines their main resources and competitiveness (availability of skilled human resources, labour and transaction costs, local market protection, and investment in education, science and research). E-clustering is longterm macroeconomic policy that initiates and pushes founding and development of e-clusters in regions.

What is the common thing between the concepts of clusters and shared value? Firstly, this is the name of Michael Porter. The concept of shared value is based on the so-called theory of corporate social responsibility, which has become very popular since the 1970's. In 2001, the European Commission gave the following definition for corporate responsibility: a concept whereby companies integrate social and environmental concerns in their business operations and in their interaction with their stakeholders on a voluntary basis (Commission of the European Communities, 2001). The term itself, as a concept, "shared value", was introduced by the authors in 2006. According to them, corporate responsibility is based on four primary pillars (Porter, Kramer, 2006):

- Maintaining moral obligations, i.e. achieving company goals by following specific ethical norms;

- Company sustainability - an attempt for satisfying current consumer needs, but not at the expense of future needs;

- License for conducting a specific activity - respecting legal and normative business requirements;

- Building up company's reputation - in terms of consumers, as well as employees and investors.

After five years, in 2011 Porter and Kramer officially introduced the concept with their paper "The big idea: Creating Shared Value" (Porter, Kramer, 2011). In this article, they define Creating Shared Value (CSV) as "creating economic value in a way that also creates value for society by addressing its needs and challenges". Other authors have also attempted to make a contribution towards the development of the concept. Pfizer et al. 'definition of shared value is “innovating to meet society's need and build a profitable 
enterprise". One contribution to the field has been made by Pfitzer et al. (2013), which suggest that in order to develop a shared value strategy; companies should follow a fivestep guide. The guide, or framework, consists of the following five steps:

- Embedding a social purpose;

- Rigorously defining the social need;

- Measuring the social and business value;

- Creating the optimal innovation structure; and

- Co-creating with external stakeholders.

After 2011, some authors (Spitzeck, Chapman, 2012) have tested the so-called theory of added value and its practical dimensions. They reached the conclusion that there is some empirical evidence of the shared value concept in practice. Others (Crane et al., 2014) do not agree entirely with the stipulation of Kramer and Porter, and point out some flaws in the theory, namely that it ignores the tensions between social and economic goals, it is naive about the challenges of business compliance is based on a shallow conception of the corporation's role in society. Still others (Lapina et al., 2012) view CSV as the next stage of development of the existing CSR concept; a new way of thinking that brings more clarity to CSR and how it fits with business. Every academic theory based on a specific corporate behaviour needs confirmation or rejection through empirical data from active companies in practice. In order to affirm it for the future, it is necessary to address the issues that shared value concept is defined with little precision, has measurement problems, overlaps with many other concepts and lacks empirical research. One of the latest studies in Indonesia examines the influence of shared value on some aspects of company results, such as financial parameters, corporate image and human resources, confirming their positive correlation (Tyas, Sukoharsono, 2014).

Creating shared value entails embedding a social mission in the corporate culture and channelling resources to the development of innovations that can help solve social problems. In some cases, this is a matter of reemphasizing firm's founding social mission. Turning the pursuit of shared value opportunities into a regular activity requires defining a clear social purpose, publicizing it internally and externally, and embedding it in core processes such as strategic planning and budgeting. This establishes a culture that unleashes the best in employees and helps mobilize external partners that have similar goals. Further the social impact of clusters' activities is particularly focused on the following conceptual business solutions:

- Inclusive Business, that has the capacity to engage business across industries in a collaborative effort with different organizations, government agencies and other network partners, to scale up action, gain greater insights, and overcome both internal and external barriers to scaling up these ventures around the world.

- Responsible Employment Strategies to address the rising unemployment, widening skills gaps, and a persistently high number of people in vulnerable employment. 
- Rural Livelihoods to enable effective cross-industry collaboration to make rural areas more attractive places to work, live and invest in.

These business solutions responds to rural challenges and tackle the root-cause of these challenges through shared understanding of rural development needs; scalable solutions for rural areas; and clarity on roles and sustainable interventions for business, governments and civil society.

\section{Rural areas and structural transformation - local economies, common problems and characteristics}

No common definition of the term rural area has so far been accepted within the European Union in the former European legislation and practice. Each Member State employs its own national definition of division of these areas. The most widely used definition in the countries of the European Union is the definition of the Organization of Economic Cooperation and Development (OECD) which determines two hierarchical levels : local = municipality LAU1 and regional $=$ district - NUTS3.

On a local level the municipalities with population density below 150 people $/ \mathrm{km}^{2}$ are defined as rural. On a regional level bigger administrative units are distinguished on the basis of the percentage of the population inhabiting each of the areas. This ratio has been applied to define the following 3 regions: predominantly rural $->50 \%$ of the population lives in the rural municipalities; rural to a considerable degree $-15-50 \%$ of the population lives in the rural municipalities; predominantly urban $-<15 \%$ of the population lives in the rural municipalities.

Each NUTS 3 region in the European Union belongs to one of the three mentioned types of areas. The methodology and the definition of the OECD are widely used in the European Union in determining their rural areas.

In 2010 a change in the methodology of the OECD was made so the weaknesses in the classification of the different regions to be overcome. This was achieved in three steps: 1) Creating clusters of urban grid cells with a minimum population density of 300 inhabitants / km2 and minimum population of 5000 people. All cells outside these urban clusters are considered rural; 2) grouped the NUTS 3 regions with territory less than $500 \mathrm{~km} 2$, with one or more neighbouring regions only for the purpose of classification; 3) classification of the NUTS 3 regions based on the proportion of the population in the rural grid cells. More than $50 \%$ of the total population in the rural grid cells defines the region as a "predominantly rural", between $20 \%$ and $50 \%$ of population in the rural grid cells is placed it in the "intermediate" region and less than $20 \%$ of population from the rural grid cells defines it as a "predominantly urban" region (A revised urban-rural typology, 2010).

According to the European Commission more than $91 \%$ of the EU territory consists of "rural areas". The population living in those areas is more than $56 \%$ of the population of the 27 Member States of the Union (Rural Development, 2014). 
Many rural areas face significant challenges. Some of their enterprises (mainly from agriculture and forestry) have yet to become competitive. The average income per capita in those areas is lower than in the urban areas, and the service sector is less developed. Furthermore, caring for the environment in rural areas is often associated with high financial costs. Agriculture and forestry remain crucial for the land use and the management of the natural resources in the rural areas of the EU, as well as a starting point for economic diversification in the rural communities. Therefore strengthening the policy for the rural development has been converted to a common priority for the Union.

On the other hand, the European rural areas have much to offer. They provide essential resources. Their value as beautiful places for recreation - as long as we take good care of them - is obvious. Many people are attracted by the idea of living and / or working there, if they have access to adequate services and infrastructure.

The lack of homogeneity of the rural areas across the EU and within Member States is a problem for the development of the programs and the vision of the European and national development policies. To give an individual response while developing solutions, the diversity and the "mix" of economic, social and cultural differences must be taken into account (IFAD, 2011).

More than half (51.3\% in 2012) of the EU's territory is within the regions classified as predominantly rural. These areas are inhabited by 112.1 million people, more than one-fifth $(22.3 \%)$ of the population of the EU-27. Only two-fifths $(38.7 \%)$ of the area and more than a third (35.3\%) of the EU population lives in medial regions in 2012, while predominantly urban areas constitute only one-tenth $(10.0 \%)$ of area, but are home to more than two-fifths $(42.4 \%)$ of the population.

The average share of population in predominantly rural areas of the EU-27 is $22.3 \%$.

Rural areas in the Balkan countries, members of the EU (Bulgaria, Greece and Romania) face common challenges: low capacity to create high quality and sustainable jobs; lower incomes than those in the urban areas; less job opportunities and not enough available jobs in a small range of economic activities. The differences between the regions have caused significant emigration flows of the rural population.

The population in the medial and rural areas of the Balkan countries in the EU-27 has decreased, especially in the rural areas in Bulgaria (-9.9 ppm), (Table 1). 
Table 1. Population and population density in Balkan countries in the EU-27

\begin{tabular}{|c|c|c|c|c|c|c|c|c|c|c|c|c|}
\hline \multirow[b]{3}{*}{ Country } & \multicolumn{6}{|c|}{2007} & \multicolumn{6}{|c|}{2012} \\
\hline & \multicolumn{2}{|c|}{$\begin{array}{l}\text { Predominantly } \\
\text { urban regions }\end{array}$} & \multicolumn{2}{|c|}{$\begin{array}{c}\text { Intermediate } \\
\text { regions }\end{array}$} & \multicolumn{2}{|c|}{$\begin{array}{c}\text { Predominantly } \\
\text { rural regions }\end{array}$} & \multicolumn{2}{|c|}{$\begin{array}{c}\text { Predominantly } \\
\text { urban regions }\end{array}$} & \multicolumn{2}{|c|}{$\begin{array}{c}\text { Intermediate } \\
\text { regions }\end{array}$} & \multicolumn{2}{|c|}{$\begin{array}{c}\text { Predominantly } \\
\text { rural reggions }\end{array}$} \\
\hline & 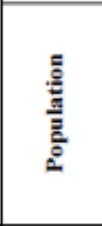 & 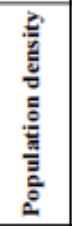 & 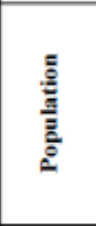 & 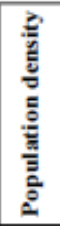 & 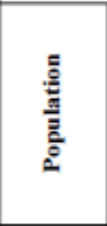 & 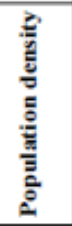 & 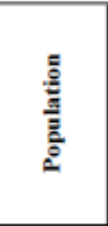 & 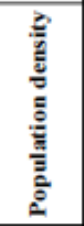 & 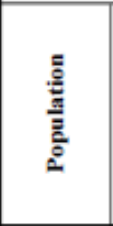 & 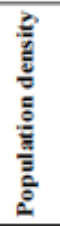 & 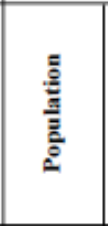 & 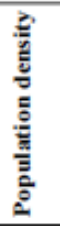 \\
\hline Bulgria & 1237891 & 918,8 & 3442498 & 68,6 & 2998901 & 50,1 & 1296615 & 1051.4 & 3282254 & 66.5 & 2748355 & 46,7 \\
\hline Greece & 5167478 & 705,2 & 1168554 & 73,8 & 4835708 & 44,9 & 5274724 & 688,0 & 1194148 & & 4821195 & 45,5 \\
\hline Romania & 2232162 & 1272,8 & 9428521 & 102,7 & 9904436 & 72,4 & 2264865 & 1286,8 & 9375778 & 102,1 & 9715206 & 71,0 \\
\hline
\end{tabular}

Source: Eurostat, 2014.

Low birth rates and higher life expectancy determine the change in the age structure of the population of the EU-27 over the next decades. As a result, the share of the working age population will be reduced while the relative number of pensioners will grow (Agriculturerural development statistics, 2014).

This development towards aging population is already apparent. The data show that relatively few people of working age live in rural areas. In 2012, the proportion of older people aged over 65 living in rural areas of the EU-27 was 18.6\% compared with an average of $17.8 \%$ in the all regions. The highest proportion of people aged 65 or over is in two regions in mainland Greece (Grevena and Evritania).

The social perspective on development emphasizes that the best route to socio-economic development, is through decent work. But the reality now speaks for itself - the level of inequality differs widely, and the income gaps have also changed to varying degrees. Additionally voices are raised not only towards the inequality of the outcome, but also about the inequality of opportunity. The share of long-term unemployment (as percentage of the total unemployment) in the EU is increasing. It has reached and surpassed its pre-crisis level, with a sharp rise in the latest quarters. 26 million people (10.8 \% of the economically active population) in the EU are looking for work. In several Member States, unemployment remains close to the historically-high levels first seen in the economic crisis. Additionally, the employment rates vary widely between European countries though several measures were initiated to improve their employability, e.g. enhancing and further developing of skills and knowledge, better support for transition to the labour market.

The employment rate for those aged 20-64 in the Member States of the Balkans as a whole is lower. The comparison of the indicators from 2007 and 2012 shows a decrease in the intermediate regions of Bulgaria with 5.8\%, while in the rural - 5.1\%. For the intermediate regions of Greece the reduction is $11.8 \%$ and for the rural - with $8.9 \%$. The intermediate regions of Romania have marked a slight increase in the values $(0.1)$, while in the rural areas there is a decrease of $1.5 \%$ (Table 2 ).

In the rural areas of Greece the employment is higher than that in the medial or predominantly urban areas. 
The difference between the level of employment in the predominantly rural and predominantly urban areas is particularly high, especially in Bulgaria (11.5\%) and Romania (5.8\%).

The unemployment rate in the rural areas of Bulgaria and Greece is a double-digit number (Table 2).

The biggest differences between the unemployment rates faced in different types of regions are registered in Bulgaria.

Table 2. Employment and unemployment rates by age from 20 to 64 years

\begin{tabular}{|c|c|c|c|c|c|c|c|c|c|}
\hline \multirow{3}{*}{ Country } & \multicolumn{6}{|c|}{$\begin{array}{c}\text { Employment rates by age from } \\
20-64 \text { years }(\%)\end{array}$} & \multicolumn{3}{|c|}{$\begin{array}{c}\text { Unemployment rates by age from } \\
20-64 \text { years }(\%)\end{array}$} \\
\hline & \multicolumn{2}{|c|}{$\begin{array}{l}\text { Predominantly } \\
\text { urban regions }\end{array}$} & \multicolumn{2}{|c|}{$\begin{array}{l}\text { Intermediate } \\
\text { regions }\end{array}$} & \multicolumn{2}{|c|}{$\begin{array}{l}\text { Predominantly } \\
\text { rural regions }\end{array}$} & $\begin{array}{l}\text { Predominantly } \\
\text { urban regions }\end{array}$ & \begin{tabular}{|l|} 
Intermediate \\
regions
\end{tabular} & \begin{tabular}{|l|} 
Predominantly \\
rural regions
\end{tabular} \\
\hline & 2007 & 2012 & 2007 & 2012 & 2007 & 2012 & & 2012 & \\
\hline Bulgaria & 77,6 & 71,2 & 68,0 & 62,2 & 64,8 & 59,7 & 7,3 & 12,6 & 14,0 \\
\hline Greece & 65,9 & 53,9 & 64,8 & 53,0 & 66,4 & 57,5 & 25,9 & 26,4 & 21,4 \\
\hline Romania & 67,8 & 67,9 & 64,4 & 64,5 & 63,6 & 62,1 & 6,1 & 6,9 & 7,3 \\
\hline
\end{tabular}

Source: Eurostat, 2014.

The sector of services contributes more than half of the total value added of the rural areas in all Member States in 2010. The exception is Romania, where agriculture, forestry and fisheries sectors have the largest contribution to the total value added.

Graph 1. GDP Euro per habitant in Balkan countries in the EU-27

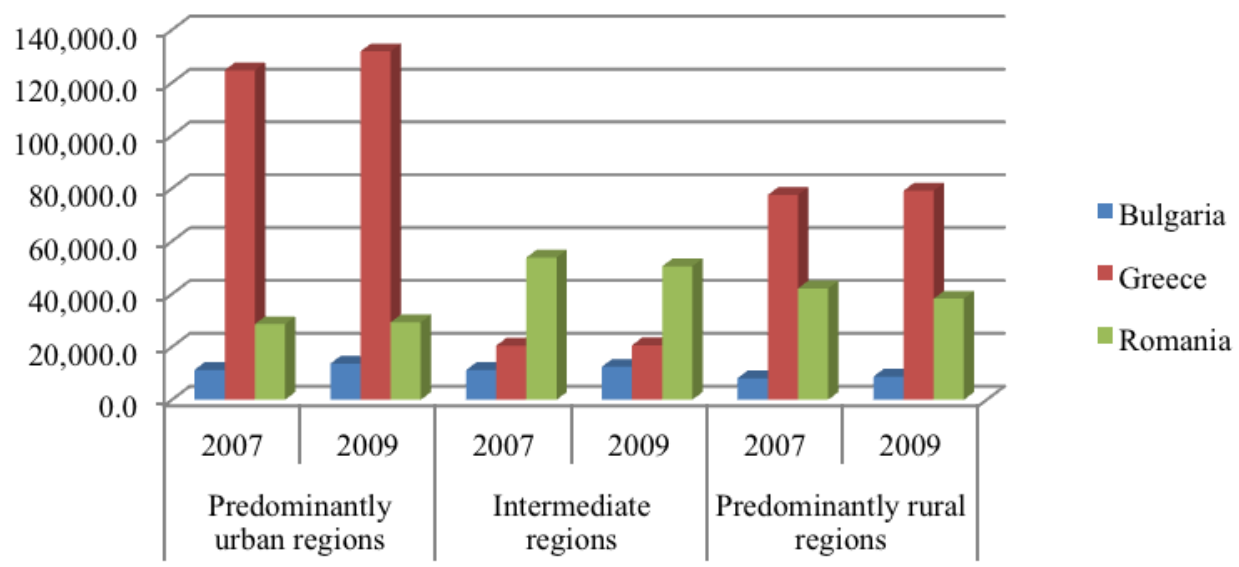

Source: Eurostat, 2014

In 2009 intermediate and predominantly rural areas of Greece with the highest levels of GDP per habitant (Graph 1). In 2010 in the rural areas of Bulgaria, Greece and Romania, the contribution of agriculture, forestry and fisheries to the total added value was higher than the contribution of the construction sector. The highest rates of gross 
value added from the agriculture, forestry and fishing are registered in Bulgaria (11.2\%) and Romania (both 11.0\%).

Although the share of agriculture, forestry and fisheries in the rural economy has reduced, the importance of diversification of the rural economy is growing (Agriculture statistics at regional level, 2014). In the EU-27 about 5.2\% of the farms have at least one other source of income.

The contribution of the agriculture to the regional economic activity is at least $5.0 \%$ in 30 regions across the EU. This includes all regions in Bulgaria and Romania (other than metropolitan areas) and seven regions in Greece.

Much of the territory of all Member States is rural and a significant number of European citizens live in those areas. Therefore it is important the regional development to be closely linked to the rural development. It must provide the conditions for increasing the quality of life in these areas, leading to a reduction of the regional disparities. Given the nature of rural areas, which have always been associated with agricultural production and food products processing, their development should be linked to the Common Agricultural Policy (CAP).

According to strategy "Europe 2020" and the overall objectives of the CAP, there are three long-term strategic objectives of the EU policy for rural development in the period 2014-2020:

- Promoting the competitiveness of agriculture;

- Ensuring sustainable management of natural resources and activities related to climate change;

- Achieve balanced territorial development of the economies and rural communities, including creating and maintaining employment.

\section{Clusters role in rural development - local economy, social capital, theory for regional economic integration}

In the past, the term "rural" was commonly used as inter-changeable concept for agricultural clusters. Recently with the emergence of rural clusters including in the field of tourism, information and communication technology, manufacturing, and renewable energy production, clusters in rurality is becoming a meaningful development trend. Clusters are effectively working in the agriculture sectors, though challenged with competition from less advanced regions, global supply chains, energy costs and environmental concerns, changes in population composition, expanding digital communications networks, new products and emerging markets.

In respect to rurality it is worth also emphasizing the extent to which debates about rural development are often preoccupied with the operation of public policy and neglect consideration of wider market trends and business and corporate strategies. Of course, this does not necessarily mean to discard the current policy framework and the dominance of the CAP or other policy instruments as key factors in influencing macro and micro-level 
management decisions, shaping environmental and other rural development interests.

The main constraints that are serving to hamper sustainability of rural areas and the stable growth of rural development include a lack of resources (financial social, informational), a lack of sufficient political will to see and admit real problems, a lack of leverage, and a lack of institutional and administrative capacity. These missing components contribute to the negative indicators and future trends in development of rural communities, identified for Bulgaria and its rural areas:

- Weak connection between key elements of the institutional system and weak internal controllability over critical processes, as they are being re-configured;

- Broad definition and measures to contribute to a new 'state of stability' for the system and, according to this, a new potential to use; and

- Need for a new configuration of key variables and processes.

Indeed clusters' capacity to set into motion significant number of direct and indirect benefits in rural areas questioned the preparedness of local conditions to foster entrepreneurial activity, production process and division of labour, joint action and local social capital. Therefore developing more systematic approach towards regional clusters and those functioning in the rural areas, especially with small business at their core level, is more than ever crucial for improving rural architecture, encouraging local authorities and proofing of the legislation and decisions made at national level.

Bulgaria has entered the European Union with a per capita income at only 73 percent of the European average and the general trend of poverty indices impose a serious risk of its ability to reproduce as a social phenomenon for the next generations. Bulgaria occupies the last place as far as income and wages are concerned. More than $22 \%$ of the population lives in risk of poverty and close to $43 \%$ live in material deprivation. The people in risk of poverty and social exclusion represent $49,1 \%$ of the Bulgarian population. Crisis has also reduced spending on health, education and social safety nets, such as insurance and thus endangers society stability and well-being. The country is with increasing unemployment rate for the past year. In 2013, the rate of unemployment in Bulgaria in the age group 15 to 74 years included (according to EUROSTAT data comparable to data about the other EU Member States) is 12.9 percent as compared to the EU 28 average of 10.9 percent and the Eurozone average of 12.1 percent. Unemployment rate in Bulgaria decreased to 11.40 percent in the second quarter of 2014 from 13 percent in the first quarter of 2014. According to the OECD definition some of the largest shares of rural population belong to the countries with higher proportion of more peripheral regions, among which is Bulgaria. These regions experience lower employment rate, insufficient infrastructure and limited access to certain social services. Nevertheless statistics are definitive towards the importance of the rural areas $-33 \%$ is the employment rate, while the contribution to the GVA is $25.1 \%$ between 2007 and 2009 the lowest GDP per capita is registered. 
According to EUROSTAT data in 2011 on predominantly rural areas ${ }^{5}$ of Bulgaria, youth (15-24 y.o.) unemployment reached $30.1 \%$ compared to the average $27.9 \%$ for Bulgaria and $22.7 \%$ for the EU-27. The highest differences between unemployment rates in the different types of regions were recorded in Bulgaria.

Graph 2. Unemployment levels per regions

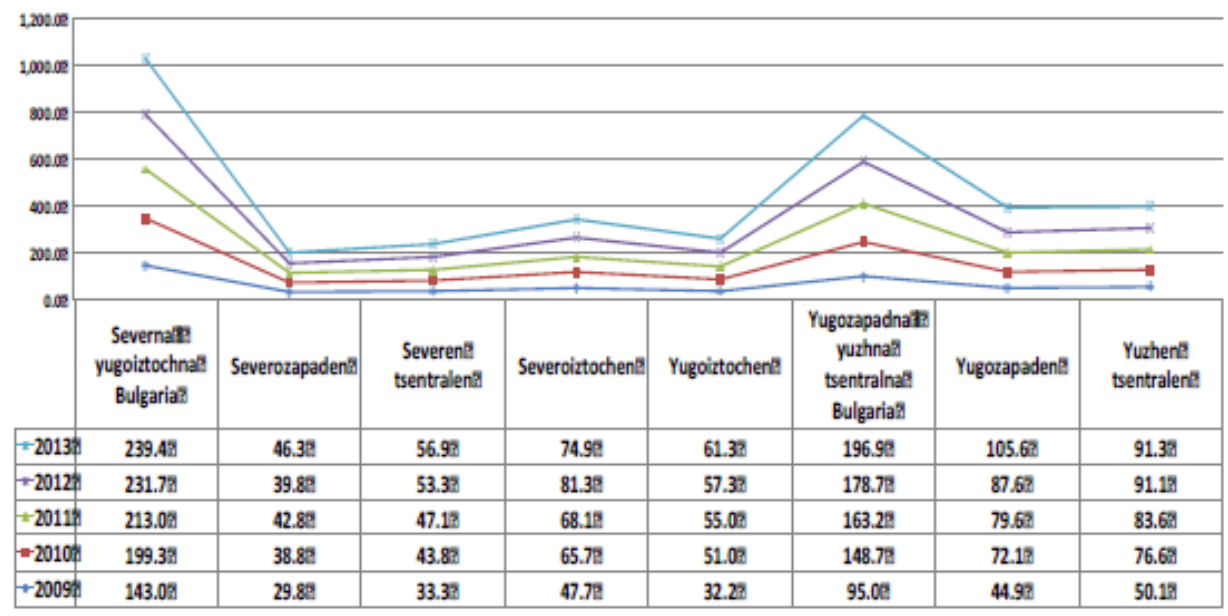

Source: Eurostat, 2014.

The country has one of the highest shares of the population at risk of poverty or exclusion as defined by the Europe 2020 strategy. The economic development in rural regions in Bulgaria, measured in GDP per capita is one of the lowest at the European level or $29 \%$ of the average GDP.

Graph 3. GPD in predominantly rural regions (mln. EUR)

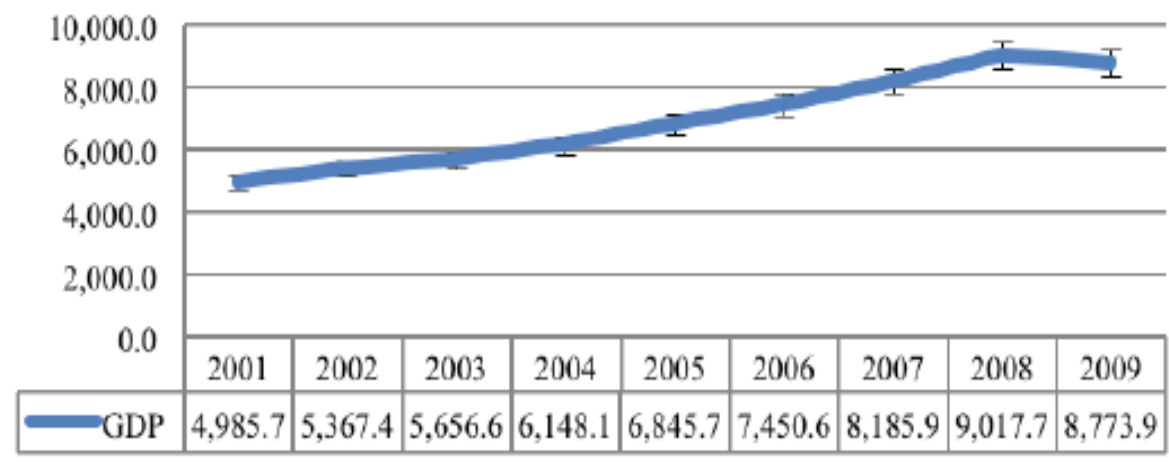

Source: Eurostat, 2014.

5 According to the typology at NUTS 3 level for predominantly rural, intermediate and predominantly urban areas from 2010, 15 from Bulgarian districts are classified as predominantly rural, 12 as intermediate and 1 as predominantly urban area: Sofia city. 
Bulgaria is among the 4 Member-states (Greece, Estonia, Bulgaria and Romania) that have reported declines of $35-38 \%$ in the agricultural labour input. The highest contributions of agriculture, forestry and fisheries to value added in predominantly rural regions were recorded in Bulgaria (11.2\%).

Historically, since 1990s series of incremental steps to reform rural and agricultural policies in Bulgaria, with the purpose to prepare the economy and institutions for the country's full-membership in the European Union (EU) have been undertaken. However, serious concerns remain about the limited scope of policy reform and the continued difficulties in resolving the various economic, social and environmental problems experienced in Bulgaria's rural areas. The effect searched through reforms was not only to increase total output but also to provide for stable productivity growth and cost optimization at microeconomic level. Reforms undertaken searched for significant changes at productionlevel and were performed simultaneously and supported by development of commercial and public institutions. Unfortunately none of these partial attempts were possible in the absence of market-based institutions and policy.

The Law for Regional Development was passed in 1999 to ensure and regulate regional policy and development and to create framework that plans and executes this policy. Six planning regions were established in accordance to government decree 145/27.02.2000 and the European criteria for regional structure NUTS-2. That way was created the territorial and statistical framework for regional development and the established new regions were included in programming of pre-accession funds of the EU. The influence of the EU accession process became a decisive factor, since the industrial policy was formed as one of the negotiating 'chapters' of the acquis, which must be taken as a requirement of the accession process. Thus, in the early 2000s Bulgaria adopted the horizontal industrial policy measures mandated by the EU. The regional development was represented by its five main priorities: Priority 1 "Increase of regional and local economic initiative"; Priority 2 "Improvement of infrastructure related to the business' development"; Priority 3 "Development of professional abilities in support to regional and local economic initiatives and transition to information society"; Priority 4 "Development of suburban regions"; Priority 5 "Increase of regional role in formulating and applying policies for regional development".

In 2004 were made the first steps in cluster creation and institutionalization, when were identified four key industrial sectors suitable for launching and supporting cluster initiatives. The first cluster organization "Bulgarian Cluster for Information and Communication Technologies Foundation (ICT Cluster)" - was registered at the end of 2004 as a nonprofit legal entity. Two more clusters were established in the early 2005, and the process was further stimulated by the PHARE project launched in mid-2005 aimed to introduce approach and model.

An integral element of the EU PHARE programme "Introduction of a cluster approach and establishing of a Cluster Pilot Model" was the delivery of a National Clusters Strategy in Bulgaria. Nowadays the Association of business clusters is the one aimed at gathering the 
Bulgarian clusters and establishing national standards and traditions in clusters policy. The particular objectives in releasing these are:

- Development and participation in preparing strategies and policies, related to social and economic development of the country;

- Research and maintenance of database of clusters in national, European and international level;

- Realize of projects for regional social and economic development, development of clusters, cross-border cooperation and others, funded by national, European and international programs;

- Membership in national and international associations and organizations.

The National Strategy for cluster development from 2006 has set priority areas to address in order to operationalize the clusters as a way whereby particular social and economic disadvantages could be tackled:

- Systemic relationships is the core characteristic of every successful cluster organization, which are difficult to establish in view of the low level of organization and limited applicability of cooperative culture;

- Geographically bound clusters could provide for specialization and preservation of historical, geographical and in general local community characteristics;

- Taking into account that the cluster itself has particular life-cycle, already existing branch organizations, representative associations could be in position to provide initial support;

- Competences and connectivity still are not mobilized to improve entrepreneurship and competitiveness, as well as to network connectivity.

27 clusters were established by that time within different industrial branches: ICT and information technologies, media, energy, tourism, food industry, textile, furniture, etc. 
Figure 1. Mapping clusters in Bulgaria

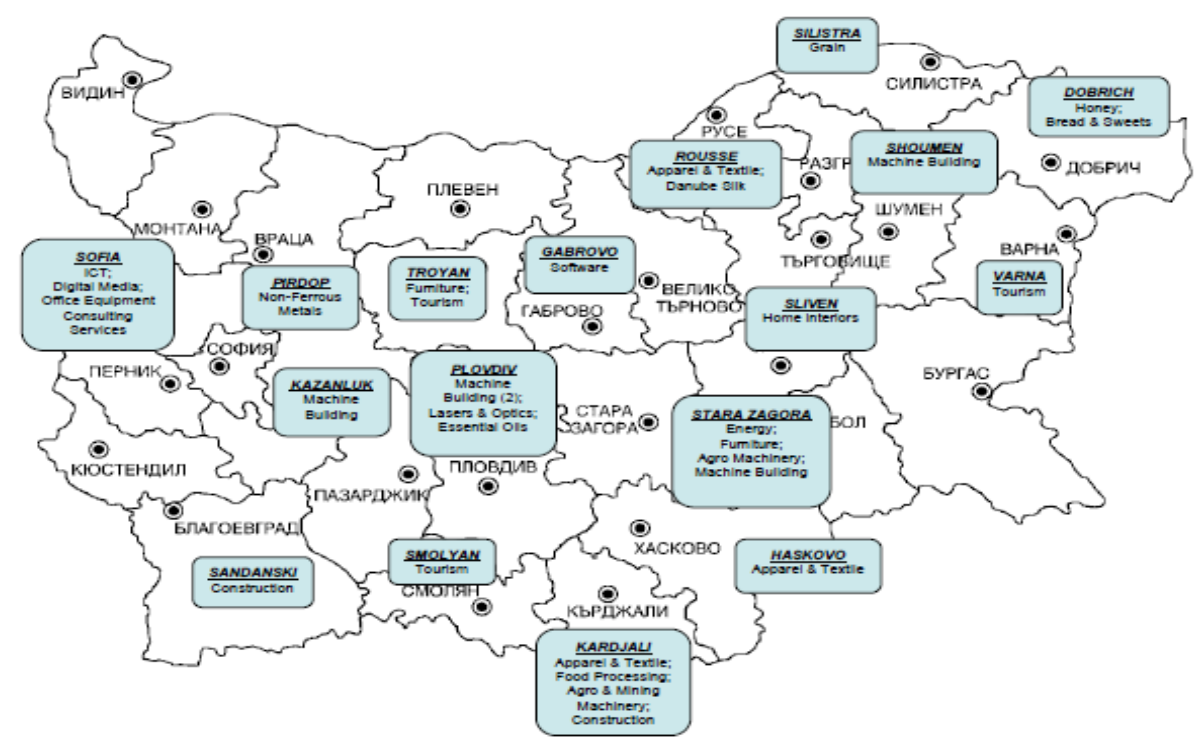

Source: Association of business clusters.

According to the Action plan for creation of clusters in Bulgaria development of 20 clusters was expected as result by the end of 2010. By 2011, Bulgarian industrial policy was claimed to be in line with the EU industrial policy approach, summarized in the National Reform Programme document for 2010-1013 adopted in April 2011. The "Support for cluster development in Bulgaria" was promoted to stimulate enterprises by receiving grants for establishing an administrative body of the cluster, for implementing projects with quick results and investment activities, in accordance with the cluster development strategy. In 2010 and in 2011, are launched calls for proposals without fixed deadlines for application for the scheme BG161PO003-2.4.01 "Support for cluster development in Bulgaria". For the period 2007-2013 the budget for the whole procedure "Promotion of business networking and clustering" (including any future calls) is EUR 15006368 . According the text of the programme, the cluster concept covers a variety of different business structures - nationalregional-cross-border clusters, clusters of competence, industrial or production systems and innovation systems. It is used for different purposes - to increase the competitiveness of SMEs, to support collective research, to rationalize a whole industry, and to implement environment management system.

To strengthen institutional support and locally established collaborations close to 60 municipalities in rural areas took part in projects for integrated development, financed by the European Union and the bilateral national programs aimed at development the capacity for planning and applying the policies for local development. In the process of structuring the development plans for the planning period 2007-2013, local action groups are involved into various collaborations - non-government organizations, educational and cultural institutions. 
In order to encourage the interest towards the opportunities provided by the Leader approach a number of projects are initiated and supported by the government. Within the framework of these projects are established eleven Local Action groups that cover 4 per cent of the rural population, other nine LAGs were in the process of setting up. Furthermore, a support to the already established local action groups is provided by sub-measure 1: "Running the Local Action Group, acquiring skills and animating the territory for selected local action groups". This sub-measure has the following objectives, e.g. to encourage development of strong and efficient LAGs; to ensure resources - human, technical, financial that are needed for the overall support and delivery of LAGs' activities and strategies; to enhance awareness and skill of local people in the Leader approach and to encourage their active participation in the process of local development strategy implementation.

The rural development programme for the next programming period 2014-2020 is built upon six thematic priorities and fifteen priority areas aimed at programme interventions, innovations and transfer of knowledge, etc. To strengthen rural development as well as the adoption of measures for promoting better and more equitable integration of the rural sectors with the rest of the national economy a better understanding is needed in terms of institutional responsibilities and priority fields.

\section{Conclusion}

The notion of clustering is hardly new, having already been described in the general economic literature, starting from the Marshall principles and following basic reasons related to minimizing costs. Indeed there is a relatively underdeveloped thematic area concerning the role of the clusters' networks in the field of social empowerment and rural development. Few cluster studies address directly poverty reduction, social inclusion, though the characteristics and the functions of the clusters themselves recognize their capabilities to further local economies, reduce vulnerability of particular economic sectors and bring about advantages for local business, institutions and society. "Clusters provide a way of organizing thinking about many policy areas that goes beyond the common needs of the entire economy. Cluster-based thinking can help focus priorities and guide policies in science and technology, education and training, export and foreign investment promotion, and a wide variety of other areas. A cluster orientation highlights the fact that more parts of government have an influence on competitiveness than normally recognized, especially within government itself. Cluster theory makes the impact of policies on competitive position much clearer and more operational. Effective solutions often require different parts of government to collaborate"'(Porter, 2000).

There are certain evidences that clusters in the early stages of industrialization can provide employment and contribute to employment growth. Usually the wage levels in clusters are usually better than in non-clustered firms or regional average wage levels, and also transaction costs are reduced, while labour sharing and sub-contracting. Additionally the growth of a cluster can disadvantage small firms or sub-contractors as they are more vulnerable to shifts in demand and may have to lose out to larger and stronger firms. Clusters and regional specialization are empirically associated with higher levels of 
innovation and prosperity. The European Cluster Observatory has provided systematic evidence that between $30 \%$ and $40 \%$ of all employment is in industries that concentrate, or 'cluster', regionally. In some regions, this share goes up to over $50 \%$ while in others it drops to $25 \%$. About $21 \%$ of these employees are employed in regions that are more than twice as specialized in a particular cluster category as the average region. In that relevance emergence of the "new rural paradigm" is considered to be well-grounded, where various sectors beyond agriculture are acknowledged to play a key role with regard to rural areas' competitiveness, and where investments across sectors are considered to be a more appropriate tool than farm subsidies alone. This shift can also be viewed as a change from an exogenous model of rural development, emphasising policy interventions "from outside", to a more endogenous approach based on the notion of rural development as a process involving multiple levels, dimensions and actors, that is also self-driven" (RUDI Rural Development Impacts).

\section{Literature}

1. A revised urban-rural typology (2010), available at: http://epp.eurostat.ec.europa.eu/ cache/ITY OFFPUB/KS-HA-10-001-15/EN/KS-HA-10-001-15-EN.PDF

2. Agriculture-rural development statistics (2014), available at: http://epp.eurostat. ec.europa.eu/statistics_explained/index.php/Agriculture _ _rural development_statistics

3. Agriculture statistics at regional level (2014), available at: $\underline{\mathrm{http}}$ //ec.europa.eu/eurostat/ statistics-explained/index.php/Agriculture statistics_at regional level

4. Association of business clusters, available at: http://abclusters.org/

5. Bergman, E. M., Feser, E. J. (1999): Industrial and Regional Clusters: Concepts and Comparative Applications, Virginia: WVU Regional Research Institute.

6. Commission of the European Communities (2001), available at: www.csr-in-commerce. eu/data/files/resources/717/com_2001 0366 en.pdf

7. Crane, A., Palazzo, G., Spence, L. J., Mattenet D. (2014): Contesting the value of "creating shared value”, California management review, University of California, Berkley, vol. 56, no. 2, pp. 130-153.

8. Davidovic, M. (2014): Development of e-clusters, Information and Communication Technology, Electronics and Microelectronics (MIPRO), 37 $7^{\text {th }}$ International Convention on, Opatija, IEEE, pp. 1563 - 1568.

9. Enright, M. J. (2000): The globalisation of competition and the localisation of competitive advantage: Policies towards regional clustering, in: Hood N., Young S. (eds.): The Globalization of Multinational Enterprise Activity and Economic Development, MacMillan: Basingstoke.

10. European Commission (2013): Refocusing EU Cohesion Policy for Maximum Impact on Growth and Jobs: The Reform in 10 points, available at: http://europa.eu/rapid/pressrelease MEMO-13-1011 bg.htm

11. European Commission (2014): Eurostat - databases, available at: http://ec.europa.eu/eurostat 
12. Feser, E. J., (1998): Old and New Theories of Industry Clusters, in: Steiner, M. (ed.), Clusters and Regional Specialisation: On Geography, Technology and Networks, London: Pion, pp. 18-40.

13. Lapina, I., Borkus, I., Starineca, O. (2012): Corporate Social Responsibility and Creating Shared Value: Case of Latvia, World Academy of Science, Engineering and Technology, vol. 6, pp. 1605-1611, available at: http://waset.org/publications/7540/ corporate-social-responsibility-and-creating-shared-value-case-of-latvia

14. Marshall, A. (1920): Principles of Economics, $8^{\text {th }}$ Edition, London: Macmillan.

15. National strategy for cluster development (2006), BG 2003/004 - 937.02.03, MYCCI, Bulgaria.

16.Palánkai, T. (2003): Economics of European Integration, Budapest: Akadémiai Kiadó, pp. 355-375.

17.Pfitzer, M., Bockstette, V., Stamp, M. (2013): Innovating for Shared Value: companies that deliver both social benefit and business value rely on five mutually reinforcing elements, Harvard Business Review, September, pp. 100-107.

18. Porter, M. E. (2007): Clusters and Economic Policy: Aligning Public Policy with the New Economics of Competition, Harvard Business School, Institute for Strategy and Competitiveness, ISC White Paper XI.

19. Porter, M. E. (1998): Clusters and the new economics of competition, Harvard Business Review, vol. 76, no. 6, pp. 77-90, P. 79.

20. Porter, M. (2000): Location, Competition and Economic Development: Local Clusters in a Global Economy, Economic Development Quarterly, vol. 14.

21. Porter, M. E. (1990): The Competitive Advantage of Nations, New York: The Free Press.

22. Porter, M. E., Kramer, M. R. (2006): Strategy and Society: the link between competitive advantage and corporate social responsibility, Harvard Business Review, vol. 84, no. 12.

23.Porter, M. E., Kramer, M. R. (2011): The big idea: creating shared value, Harvard Business Review, Boston MA, Jan-Feb 2011, pp. 1-17.

24. Roelandt, T., den Hertog, P. (1999): Cluster analysis and cluster-based policy making in OECD countries: an introduction to the theme, chapter 1 in $\mathrm{OECD}$, Boosting innovation: the cluster approach, Paris: OECD, pp. 9-23.

25. Rosenfeld, S. (2009): Generating Local Wealth, Opportunity, and Sustainability through Rural Clusters, Wealth Creation in Rural Communities, vol. 1, Regional Technology Strategies, Inc., p. 9.

26. Rural Development 2014-2020 (2014), available at: http://ec.europa.eu/agriculture/ rurdev/index bg.htm

27. International Fund for Agricultural Development (IFAD), (2011): Rural Poverty Report 2011, available at: www.ifad.org/rpr2011/report/e/rpr2011.pdf

28. RuDi Rural Development Impacts, available at: www.rudi-europe.net 
29. Sölvell, Ö., Lindqvist, G., Ketels, Ch. (2003): The Cluster Initiative Greenbook, Stockholm, available at: www.cluster-research.org/greenbook.htm, accessed April 2011.

30. Spitzeck, H., Chapman, S. (2012): Creating shared value as a differentiation strategy-the example of BASF in Brazil. Corporate Governance, vol. 12, no. 4, pp. 499-513.

31. Stejskal, J., Hajek, P. (2012): Competitive advantage analysis: a novel method for industrial clusters identification, Journal of Business Economics and Management, vol. 13, no. 2, pp. 344-365.

32. Tyas, F. H., Sukoharsono, E. G. (2014): The implementation of creating shared value $(C S V)$ and its impact on company's performance, Jurnal Ilmiah Mahasiswa, FEB, vol. 2, no. 2, Semester Genap 2013/2014, available at: http://jimfeb.ub.ac.id/index.php/ jimfeb/article/view/1150/1059 